\title{
HUBUNGAN KEBIASAAN OLAHRAGA, RASIO LINGKAR PINGGANG PINGGUL, DAN KEBIASAAN MEROKOK DENGAN KADAR KOLESTEROL TOTAL PASIEN POLIKLINIK JANTUNG
}

\section{The Relationship of Sports Habits, Circumference Waist Hip Ratio, and Smoking Habits with Total Cholesterol Levels Heart Policlinic Patients}

\author{
Reni Purnama Indah Lestari', Harna ${ }^{1}$, Anugrah Novianti ${ }^{1}$ \\ 1Program Studi Gizi Fakultas IImu-IImu Kesehatan Universitas Esa Unggul \\ J. Arjuna Utara No.9, Kebon Jeruk, Jakarta 11510 \\ e-mail: harna@esaunggul.ac.id
}

\begin{abstract}
ABSTRAK
Kadar kolesterol yang tinggi berkontribusi sebesar 56\% sebagai faktor dalam penyebab terjadinya PJK. Penyakit jantung koroner (PJK) adalah penyakit jantung dan pembuluh darah yang disebabkan karena penyempitan arteri koroner. Tujuan dari analisis ini adalah untuk mengetahui hubungan kebiasaan olahraga, RLPP, pola konsumsi, tingkat kecukupan serat, dan kebiasaan merokok dengan kadar kolesterol total pasien poliklinik jantung RSUD Banten. Jenis penelitian ini menggunakan desain cross sectional, dengan sampel sebanyak 96 responden yaitu pasien poliklinik jantung. Analisis data yang digunakan dalam penelitian ini adalah uji ChiSquare. Hasil analisis didapat Responden dengan status gizi normal sebanyak $66.70 \%$, responden yang mengonsumsi obat penurun kolesterol sebanyak 55.2\%. Responden dengan kadar kolesterol normal sebanyak $53.10 \%$, responden dengan kebiasaan olahraga sebanyak $56.25 \%$, responden dengan RLPP beresiko sebanyak $71.87 \%$, responden tidak merokok sebanyak $66.70 \%$. Terdapat hubungan antara kebiasaan olahraga, rasio lingkar pinggang pinggul, terhadap kadar kolesterol total $(\mathrm{p}<0,05)$. sedangkan tidak terdapat hubungan antara kebiasaan merokok terhadap kadar kolesterol total $(p>0,05)$. Kesimpulan pada penelitian ini adalah kebiasaan olahraga, RLPP, mempengaruhi kadar kolesterol total sedangkan kebiasaan merokok tidak mempengaruhi kadar kolesterol total.
\end{abstract}

Kata Kunci: Kebiasaan Olahraga, RLPP, Kebiasaan Merokok, Kadar Kolesterol Total

\section{ABSTRACT}

High cholesterol levels constitute 56\% of the factors that contribute greatly to the cause of CHD. Coronary heart disease (CHD) is a disease of the heart and blood vessels caused by narrowing of the coronary arteries. The purpose of this study to analyze the relationship of sports habits, circumference waist hip ratio, consumption pattern, level of fiber adequacy, and smoking habits with total cholesterol levels heart policlinic patients RSUD Banten. This type of research uses a cross sectional design, with a sample of 96 respondents namely heart policlinic patients. Analysis of the data used in this study is the Chi-square test. The Results show Respondents with normal nutritional status were $66.70 \%$, respondents who consumed cholesterol-lowering drugs were $55.2 \%$. Respondents with normal cholesterol levels were $53.10 \%$, respondents with exercise habits were $56.25 \%$, respondents with RLPP were at a risk of $71.87 \%$. Respondents did not smoke as much as $66.70 \%$. There was a relationship between exercise habits, hip waist circumference ratio, to total cholesterol levels ( $p<0.05)$. There is no relationship between smoking habits on total cholesterol levels ( $p>0.05$ ). This study concluded that the sports habits, RLPP, affect total cholesterol levels, while smoking does not affect total cholesterol levels.

Keyword: Sports Habits, RLPP, Smoking Habits, Total Cholesterol Levels. 


\section{PENDAHULUAN}

Kemajuan teknologi berdampak terhadap perubahan gaya hidup dan pola makan masyarakat. Pada masa kini, pola makan masyarakat mengalami perubahan seiring peningkatan popularitas berbagai hidangan atau makanan siap saji. Masyarakat dimanjakan oleh fasilitas dan kemudahan yang disediakan restoran siap saji. Mereka tidak lagi mengkonsumsi makanan seimbang yang terdiri dari beraneka ragam jenis makanan dengan kandungan zat gizi lengkap dan seimbang, tetapi cenderung makan mengandung tinggi lemak terutama lemak jenuh, kolesterol dan rendah serat. ${ }^{1}$ Akibat pola makanan cepat saji dan gaya hidup yang serba instan, prevalensi obesitas meningkat duakali lipat pada tahun diantara 1980 dan 2014. ${ }^{12}$

Salah satu penyakit yang ditimbulkan akibat dari pola hidup dan pola makan yang kurang seimbang adalah hiperkolesterol, tingginya konsumsi makanan yang mengandung lemak jenuh dapat meningkatkan kadar kolesterol dalam darah atau hiperkolesterolemia. ${ }^{1}$

Kolesterol adalah komponen lemak darah, dan diketahui bahwa lemak merupakan zat yang di butuhkan tubuh selain protein, vitamin, mineral dan karbohidrat. Lemak dalam tubuh berguna untuk membentuk dinding sel-sel tubuh. Kolesterol yang dibutuhkan secara normal diproduksi sendiri dalam jumlah yang tepat. Namun kolesterol juga dapat meningkat jika sering mengkonsumsi makanan dengan kadar lemak hewan tinggi (otak sapi, daging merah, seafood, kuning telur, keju, dll) atau makanan cepat saji . ${ }^{2}$

Kolesterol berguna bagi tubuh, namun jika jumlahnya berlebihan cenderung menimbulkan penyakit. $^{10}$ Kadar kolesterol total yang tinggi akan membentuk aterosklerosis yang dapat menyebabkan hipertensi dan penyumbatan pada pembuluh darah otak, jantung, dan pembuluh darah tungkai. ${ }^{11}$

Berdasarkan Riskesdas tahun 2013 prevalensi hiperkolesterolemia pada kelompok usia 25-34 tahun sebesar 9,3\% dan meningkat sesuai pertambahan usia hingga 15,5\% pada kelompok usia 55-64 tahun. Pada penduduk $>15$ tahun didapatkan kolesterol total abnormal sebesar $35.9 \%$. $^{3}$

$$
\text { Faktor resiko terjadinya }
$$
hiperkolesterolimia, terbagi menjadi dua kategori yaitu faktor risiko yang dapat dikendalikan atau dimodifikasi dan faktor risiko yang tidak dapat dimodifikasi. Faktor risiko yang dapat dimodifikasi antara lain kegemukan, asupan kolesterol, asupan serat rendah, asupan lemak tinggi, aktivitas fisik yang rendah, perubahan keadaan sosial stress, dan merokok. Sedangkan faktor risiko yang tidak dapat dikendalikan yaitu genetik, jenis kelamin, usia, geografis, dan ras. ${ }^{4}$

Kadar kolesterol yang tinggi merupakan $56 \%$ faktor yang berkontribusi besar dalam penyebab terjadinya PJK. ${ }^{6}$ Penyakit jantung koroner merupakan penyebab kematian 
terbesar, diperkirakan 17 juta orang meninggal tiap tahunnya karena penyakit jantung koroner. Tingginya angka penyakit jantung koroner sejalan dengan bergesernya perubahan pola penyakit kearah yang terkait abnormalitas metabolisme seperti obesitas, dislipidemia dan hipertensi. ${ }^{9}$

Kolesterol dalam darah ditransport oleh lipoprotein, diantaranya ada dua jenis lipoprotein utama, yaitu Low Density Lipoprotein (LDL) dan High Density Lipoprotein (HDL). Konsekuensi hiperlipidemia yang paling penting adalah peningkatan kolesterol serum, terutama peningkatan LDL yang merupakan predisposisi terjadinya aterosklerosis serta meningkatnya risiko terjadinya $\mathrm{PJK}^{5}$ Sedangkan HDL bersifat protektif terhadap kemungkinan pengendapan aterosklerosis. Hasil penelitian menunjukkan konsentrasi tinggi kolesterol HDL dalam sirkulasi membantu mencegah PJK. Hiperkolesterolemia adalah salah satu gangguan lemak dalam darah, Kadar kolesterol total dalam darah tidak boleh lebih dari $240 \mathrm{mg} / \mathrm{dL}^{6}$

Kolesterol bila terdapat dalam jumlah terlalu banyak di dalam darah dapat membentuk endapan pada dinding pembuluh darah sehingga menyebabkan penyempitan yang dinamakan ateroskleresis. Bila penyempitan terjadi pada pembuluh darah jantung dapat menyebabkan penyakit jantung koroner dan bila pada pembuluh darah otak yaitu serebrovaskuler. ${ }^{7}$
Produksi kolesterol yang meningkat akan menyumbat pembuluh darah, akibatnya, aliran darah yang melewati pembuluh darah menjadi tidak lancar. Oksigen yang dibawa oleh darah untuk mensuplai jantung dan otak otomatis menjadi lebih sedikit. Karena itu terjadi ketidakseimbangan antara oksigen supply dan oksigen demand. Inilah yang akan menjadi cikal-bakal terjadinya penyakit jantung koroner (PJK) dan stroke. ${ }^{8}$

\section{METODE PENELITIAN}

Jenis penelitian yang digunakan adalah penelitian deskriptif analitik dengan pendekatan studi cross-sectional. Variabel penelitian meliputi variabel independen (bebas) yaitu kebiasaan olahraga, rasio lingkar pinggang pinggul (RLPP), pola konsumsi, tingkat kecukupan serat, kebiasaan merokok, sedangkan variabel dependen (terikat) yaitu kadar kolesterol total pada pasien yang terdaftar di poliklinik jantung RSUD Banten.

Populasi dalam penelitian ini adalah seluruh pasien rawat jalan poliklinik jantung RSUD Banten. Teknik pengambilan sampel yang digunakan dalam penelitian ini dilakukan secara Non Probability Sampling dengan metode Accidental Sampling, dalam pengumpulan sampel yang dilakukan dalam penelitian ini didapat sebanyak 96 responden.

Jenis data yang dikumpulkan yaitu, data primer yang diperoleh secara langsung dari sampel yang meliputi: 1. Identitas Responden, untuk mendapatkan data 
karakteristik responden meliputi nama, umur, status gizi, dan jenis obat yang dikonsumsi.

2. Kebiasaan Olahraga yaitu data mengenai kebiasaan olahraga, dan berapa kali dilakukan selama seminggu, 3. Rasio Linggkar Pinggang Pinggul yaitu data mengenai hasil pengukuran nilai lingkar pinggang yang dibandingkan dengan nilai lingkar pinggul yang diperoleh dengan cara pengukuran menggunakan metode Antropometri. 4. Kebiasaan Merokok yaitu data mengenai kebiasaan merokok pasien diperoleh dengan cara wawancara menggunakan metode kuesioner. Analisis data menggunakan uji chi-square dengan $\alpha=0.05$.

\section{HASIL}

\section{Karakteristik Responden}

Hasil analisis berdasarkan umur responden menunjukkan bahwa umur responden terbanyak adalah dalam rentang usia 50-60 tahun yaitu sebesar 64\%, dengan status gizi normal sebesar $66.7 \%$, dan sebagian besar mengonsumsi obat penurun kolesterol yaitu sebesar 55.2\% (Tabel 1).

\begin{tabular}{|c|c|c|}
\hline Karakteristik & $\mathbf{n}$ & $\%$ \\
\hline \multicolumn{3}{|l|}{ Umur } \\
\hline $45-49$ & 35 & 36.0 \\
\hline $50-60$ & 61 & 64.0 \\
\hline \multicolumn{3}{|l|}{ Status Gizi } \\
\hline Normal & 64 & 66.7 \\
\hline Overweight & 32 & 33.3 \\
\hline \multicolumn{3}{|l|}{ Konsumsi Obat } \\
\hline Mengonsumsi Obat & 53 & 55.2 \\
\hline Tidak Mengonsumsi Obat & 43 & 44.8 \\
\hline
\end{tabular}

\section{Analisis Univariat}

Hasil analisis univariat ini terdiri dari kadar kolesterol total, kebiasaan olahraga, rasio lingkar pinggang pinggul (RLPP), dan kebiasaan merokok. Pada penelitian ini responden paling banyak memiliki kadar kolesterol total normal sebesar $53.1 \%$, dan responden yang memiliki kadar kolesterol total tinggi sebesar $46.9 \%$. Untuk kebiasaan olahraga pada penelitian ini responden paling banyak memiliki kebiasaan olahraga sebesar $56.25 \%$, dan responden tidak memiliki kebiasaan olahraga sebesar $43.75 \%$. Untuk rasio lingkar pinggang pinggul pada penelitian ini paling banyak responden yang memiliki rasio lingkar pinggang pinggul beresiko yaitu sebesar $70.8 \%$, dan responden yang memiliki rasio lingkar pinggang pinggul normal sebesar $29.2 \%$, dan untuk kategori kebiasaan merokok pada penelitian ini responden didominasi tidak memiliki kebiasaan merokok yaitu sebesar $66.7 \%$, dan responden yang memiliki kebiasaan merokok sebesar 33.3\% (Tabel 2).

\section{Analisis Bivariat}

\section{Kebiasaan Olahraga dengan Kadar}

\section{Kolesterol Total}

Responden yang memiliki kebiasaan olahraga lebih banyak memiliki kadar kolesterol total normal sebesar $62.9 \%$, sedangkan responden yang tidak memiliki kebiasaan olahraga lebih banyak memiliki kadar kolesterol total tinggi sebesar 59.5\%. 
Tabel 2 Distribusi Hubungan Kebiasaan Olahraga dan Rasio Lingkar Pinggang Pinggul serta Kebiasaan Merokok dengan Kadar Kolesterol Total Responden Poliklinik Jantung RSUD Banten

\begin{tabular}{|c|c|c|c|c|c|c|c|c|}
\hline \multirow{3}{*}{ Variabel } & \multicolumn{6}{|c|}{ Kolesterol Total } & \multirow{3}{*}{$\mathbf{p}$} & \multirow{3}{*}{ OR } \\
\hline & \multicolumn{2}{|c|}{ Normal } & \multicolumn{2}{|c|}{ Tinggi } & \multicolumn{2}{|c|}{ Jumlah } & & \\
\hline & $\mathbf{n}$ & $\%$ & $\mathbf{n}$ & $\%$ & $\mathbf{n}$ & $\%$ & & \\
\hline \multicolumn{9}{|c|}{ Kebiasaan Olahraga } \\
\hline Olahraga & 34 & 62.9 & 20 & 37.1 & 54 & 100 & 0.047 & 2.500 \\
\hline Tidak olahraga & 17 & 40.5 & 25 & 59.5 & 42 & 100 & & \\
\hline \multicolumn{9}{|c|}{ Rasio Lingkar Pinggang Pinggul } \\
\hline Normal & 19 & 70.4 & 8 & 29.6 & 27 & 100 & 0.049 & 2.746 \\
\hline Beresiko & 32 & 46.4 & 37 & 53.6 & 69 & 100 & & \\
\hline \multicolumn{9}{|l|}{ Kebiasaan Merokok } \\
\hline Tidak merokok & 37 & 57.8 & 27 & 42.2 & 64 & 100 & 0.278 & \\
\hline Merokok & 14 & 43.7 & 18 & 56.3 & 32 & 100 & & \\
\hline Total & 51 & 53.1 & 45 & 46.9 & 96 & 100 & & \\
\hline
\end{tabular}

Kebiasaan olahraga didapat dari form kuesioner dan kemudian diuji dengan uji Chisquare. Berdasarkan hasil uji statistik didapatkan p-value pada $\alpha 0,05=0,047$. Hal ini menunjukkan bahwa ada hubungan antara kebiasaan olahraga dengan kadar kolesterol total pasien di poliklinik jantung RSUD Banten, dengan nilai OR 2.5 yang artinya responden yang tidak memiliki kebiasaan olahraga mempunyai risiko 2.5 kali lebih besar memiliki kadar kolesterol total tinggi. dibandingkan dengan responden yang memiliki kebiasaan olahraga (Tabel 2).

\section{Rasio Lingkar Pinggang Pinggul dengan Kadar Kolesterol Total}

Responden yang memiliki rasio lingkar pinggang pinggul normal lebih banyak memiliki kadar kolesterol total normal sebesar $71.4 \%$, sedangkan responden yang memiliki rasio lingkar pinggang pinggul beresiko lebih banyak memiliki kadar kolesterol total tinggi sebesar 54.4\%.

Rasio lingkar pinggang pinggul didapat dari pengukuran langsung kepada responden lalu dituliskan pada form kuesioner dan kemudian diuji dengan uji Chi-square. Berdasarkan hasil uji statistik didapatkan pvalue pada $\alpha \quad 0,05=0,037$. Hal ini menunjukkan bahwa ada hubungan antara rasio lingkar pinggang pinggul dengan kadar kolesterol total pasien di poliklinik jantung RSUD Banten, dengan nilai OR 2.984 yang artinya responden yang memiliki rasio lingkar pinggang pinggul dengan kategori beresiko mempunyai risiko 2.984 kali lebih besar memiliki kadar kolesterol total tinggi. dibandingkan dengan responden yang memiliki rasio lingkar pinggang pinggul dengan kategori normal (Tabel 2). 
Kebiasaan Merokok dengan Kadar Kolesterol Total

Responden yang tidak memiliki kebiasaan merokok lebih banyak memiliki kadar kolesterol total normal sebesar 57.8\%, sedangkan responden yang memiliki kebiasaan merokok lebih banyak memiliki kadar kolesterol total tinggi sebesar 56.3\%.

Kebiasaan merokok didapat dari form kuesioner dan kemudian diuji dengan uji Chisquare. Berdasarkan hasil uji statistik didapatkan p-value pada $\alpha 0,05=0,278$. Hal ini menunjukkan bahwa tidak ada hubungan antara kebiasaan merokok dengan kadar kolesterol total pasien di poliklinik jantung RSUD Banten (Tabel 2).

\section{PEMBAHASAN}

\section{Kadar Kolesterol Total}

Responden dalam penelitian ini adalah pasien yang terdaftar di Poliklinik Jantung RSUD Banten, pada penelitian ini terdapat $53.1 \%$ responden paling banyak memiliki kadar kolesterol total normal, dan sebesar $46.9 \%$ responden memiliki kadar kolesterol total tinggi. Untuk mengetahui kadar kolesterol total dengan cara melihat hasil rekam medik responden.

Kolesterol adalah sterol (sekelompok senyawa yang mempunyai karakteristik struktur cincin kompleks steroid) yang paling dikenal oleh masyarakat. Kolesterol di dalam tubuh mempunyai fungsi ganda, yaitu di satu sisi diperlukan dan di sisi lain dapat membahayakan bergantung berapa banyak terdapat di dalam tubuh dan di bagian mana. ${ }^{13}$

Kolesterol merupakan zat sejenis sterol yang paling banyak dalam plasma darah. Dalam keadaan normal kolesterol disintesis dalam hati yang akan menyumbang sekitar $75 \%$ dari total kolesterol dalam aliran darah, sedangkan selebihnya diperoleh dari makanan. Kolesterol merupakan komponen utama pembentukan sel otak dan saraf. Kolesterol juga berfungsi sebagai bahan pembentuk (prekursor) asam empedu, serta steroid hormon seperti estrogen, testosteron, dan kortisol. ${ }^{14}$

Kolesterol bila terdapat dalam jumlah terlalu banyak di dalam darah dapat membentuk endapan pada dinding pembuluh darah sehingga menyebabkan penyempitan yang dinamakan ateroskleresis. Bila penyempitan terjadi pada pembuluh darah jantung dapat menyebabkan penyakit jantung koroner dan bila pada pembuluh darah otak yaitu serebrovaskuler. ${ }^{7}$

\section{Hubungan Kebiasaan Olahraga dengan}

\section{Kadar Kolesterol Total}

Berdasarkan hasil analisa univariat diketahui bahwa responden paling banyak memiliki kebiasaan olahraga sebesar $56.25 \%$, dan sebesar $43.75 \%$ responden tidak memiliki kebiasaan olahraga. Kebiasaan olahraga yang sering dilakukan oleh responden di poliklinik Jantung RSUD Banten adalah lari pagi atau jogging sebanyak 3-5 kali seminggu dengan durasi 
rata rata 1 jam, selain itu ada juga responden yang berolahraga dengan cara bersepeda, berenang, dan ikut kegiatan senam rutin yang diadakan oleh ketua RT di tempat tinggal responden sebanyak 3 kali seminggu dengan durasi $>30$ menit.

Hasil dari analisa bivariat kebiasaan olahraga yang didapat dari responden yang berada di Poliklinik Jantung RSUD Banten diperoleh nilai p 0,047<0.005 $(\alpha)$, menunjukan adanya hubungan signifikan antara kebiasaan olahraga dengan kadar kolesterol total.

Olahraga yang dilakukan secara intens menyebabkan perubahan fisiologis yang sehat pada jantung dan sistem peredaran darah. Sirkulasi ke seluruh tubuh meningkat dan jantung menjadi kuat serta denyutan untuk memompa darah berkurang. Oksigen dan zat-zat gizi mencapai sel-sel tubuh dan zat-zat sisa dibawa keluar secara efisien. Elastisitas paru-paru meningkat sehingga lebih banyak udara yang masuk ke sel-sel tubuh dan dapat memperlambat degenerasi akibat usia. Latihan olahraga merupakan suatu aktivitas fisik, yang bermanfaat untuk meningkatkan dan mempertahankan kesehatan dan daya tahan jantung, paru, peredaran darah, otot-otot, dan sendi-sendi. ${ }^{10}$

Olahraga yang dilakukan secara teratur memberikan pengaruh yang besar terhadap tubuh. Latihan fisik dengan pembebanan tertentu akan mengubah faal tubuh yang selanjutnya akan mengubah tingkat kesegaran jasmani. Perubahan secara cepat adalah respon, bila perubahannya lambat akibat olahraga atau latihan teratur disebut adaptasi. Aktivitas aerobik teratur menurunkan risiko PJK, meskipun hanya $11 \%$ laki-laki dan $4 \%$ perempuan. ${ }^{15}$ Selain itu olahraga yang terperogram akan mempunyai beberapa manfaat diantaranya adalah untuk mempertahankan kesehatan, meningkatkan kekutan otot jantung, meningkatkan sirkulasi dalam tubuh, menurunkan kadar lemak, menguatkan otot-otot tubuh, mengurangi stress, dan ketenangan batin. ${ }^{10}$

Hasil penelitian ini sejalan dengan hasil penelitian yang dilakukan Oktaviasari dari 92 sampel responden yang tidak berolah raga sebanyak 74 orang (80.4\%). Berdasarkan hasil bivariatnya menunjukkan hubungan bermakna antara olahraga dengan penyakit jantung koroner. ${ }^{16}$

Dalam penelitian Salim dkk menyatakan olahraga bukan merupakan penyebab utama terjadinya PJK, akan tetapi pada orang yang rutin berolahraga dapat menurunkan risiko penyakit jantung koroner. Orang yang tidak berolahraga berisiko lebih besar terkena penyakit jantung koroner 2.250 kali lebih besar dibandingkan dengan responden yang rutin berolahraga. ${ }^{17}$.

\section{Hubungan Rasio Lingkar Pinggang Pinggul dengan Kadar Kolesterol Total}

Berdasarkan hasil analisa univariat diketahui bahwa paling banyak responden yang memiliki rasio lingkar pinggang pinggul beresiko yaitu sebesar $71.87 \%$, dan 
sebesar $28.13 \%$ responden yang memiliki rasio lingkar pinggang pinggul normal. Ratarata rasio lingkar pinggang pinggul responden dipoliklinik jantung RSUD Banten adalah $0.97 \mathrm{~cm}$.

Hasil dari analisa bivariat rasio lingkar pinggang pinggul dengan kadar kolesterol total pasien di poliklinik jantung RSUD Banten diperoleh nilai p $0.049<0.005(\alpha)$, menunjukan adanya hubungan signifikan antara rasio lingkar pinggang pinggul terhadap kadar kolesterol total.

Lingkar pinggang sebagai salah satu parameter juga dapat memprediksi distribusi lemak tubuh di dalam rongga perut dapat digunakan untuk mengidentifikasi individu dengan risiko terkena penyakit metabolik dan penyakit kardiovaskular, termasuk disini yaitu hiperkolesterolemia.

Hiperkolesterolemia ini erat hubungannya dengan mekanisme terjadinya atherosklerosis, dimana atherosklerosis berhubungan erat dengan peningkatan kadar kolesterol total dan LDL dalam darah. ${ }^{13}$

Peningkatan lemak dalam perut akan menyebabkan kelainan metabolisme lipid. Kelainan kadar fraksi lipid yang utama adalah kenaikan kadar kolesterol total, kenaikan Low density Lipoprotein (LDL), kenaikan kadar trigliserida, dan penurunan kadar kolesterol High Density Lipoprotein (HDL). Lemak dalam rongga perut merupakan salah satu pemicu terjadinya penyakit kardiovaskuler yang dapat diketahui dari hasil pengukuran lingkar pinggang dan pinggul. ${ }^{18}$

Menurut Ayuandira (2012) Obesitas merupakan suatu keadaan dengan akumulasi lemak yang tidak normal di jaringan adiposa sehingga dapat mengganggu kesehatan. Obesitas berhubungan dengan lipoprotein, penurunan HDL, peningkatan trigliserida dan LDL, terutama obesitas sentral. Rasio lingkar pinggang dan pinggul (RLPP) dihitung dengan membagi ukuran lingkar pinggang dengan lingkar pinggul. ${ }^{19}$ Ukuran lingkar pinggang, menggambarkan tingginya simpanan lemak berbahaya di dalam tubuh, sementara lingkar pinggul merupakan faktor protektif terhadap kejadian penyakit kardiovaskuler. Pengukuran ini tiga kali lebih besar dibandingkan dengan IMT dalam merefleksikan keberadaan lemak berbahaya dalam dinding abdomen. ${ }^{20}$

Hasil penelitian ini juga menunjukkan bahwa responden yang rasio lingkar pinggang pinggunlnya normal memiliki risiko kecil untuk mengalami kadar kolesterol total tinggi, terkena penyakit jantung koroner daripada yang lingkar pinggang pinggulnya lebih dari normal.

Pengukuran rasio lingkar pinggang pinggul lebih sensitif dalam menilai distribusi lemak dalam tubuh terutama yang berada didinding abdomen. Rasio lingkar pinggang pinggul dihitung dengan membagi ukuran lingkar pinggang dengan lingkar pinggul. Ukuran lingkar pinggang, menunjukan tingginya simpanan lemak 
berbahaya dalam tubuh, sementara lingkar pinggul merupakan faktor protektif terhadap kejadian penyakit kardiovaskuler. ${ }^{20}$

Penelitian ini sejalan dengan penelitian yang dilakukan maryani (2013) menunjukkan bahwa ada hubungan antara rasio lingkar pinggang pinggul terhadap kejadian penyakit jantung koroner di RSUD Kabupaten Sukoharjo $(\mathrm{p}$ value $=0.007) .{ }^{21}$

Hasil penelitian Sunarti (2013) juga menyatakan penderita PJK sebagian besar juga memiliki rasio lingkar pinggang pinggul berisiko (60\%) serta diperoleh bahwa terdapat hubungan antara rasio lingkar pinggang pinggul dengan penyakit jantung koroner $(\mathrm{p}=0.009){ }^{22}$

Banyaknya penelitian telah menunjukan bahwa ada hubungan antara rasio perbandingan lingkar pinggang dan pinggul dalam kaitannya dengan tingginya lemak di daerah perut. Menurut Tenta Septina (2010) yang melakukan penelitian studi validasi terhadap rasio lingkar pinggang pinggul, mengatakan bahwa rasio lingkar pinggang pinggul dapat digunakan untuk mendeteksi hiperkolesterolemia. Selain itu melihat tingginya angka kolesterol, rasio lingkar piggang pinggul dapat digunakan untuk mendeteksi kegemukan, karena semakin besar rasio baik pinggang atapun pinggul akan memperlihatkan kegemukan di bagian pinggang ataupun pinggul. Untuk itu rasio lingkar pinggang pinggul dapat dideteksi untuk melihat kegemukan pada diri seseorang. ${ }^{23}$
Hubungan Kebiasaan Merokok dengan

\section{Kadar Kolesterol Total}

Berdasarkan hasil analisa univariat diketahui bahwa responden paling banyak tidak memiliki kebiasaan merokok yaitu sebesar $66.7 \%$, dan sebesar $33.3 \%$ responden yang tidak memiliki kebiasaan merokok.

Hasil dari analisa bivariat kebiasaan merokok dengan kadar kolesterol total pasien di poliklinik jantung RSUD Banten diperoleh nilai p $0.278>0.005(\alpha)$, menunjukan tidak adanya hubungan yang signifikan antara asupan serat dengan kadar kolesterol total.

Efek negatif dari merokok adalah menyebabkan beban miokard bertambah karena rangsangan oleh katekolamin dan menurunnya konsumsi $\mathrm{O} 2$ akibat inhalasi $\mathrm{CO}$ atau dengan perkataan lain merokok dapat menyebabkan tahikardi, vasokonstruksi pembuluh darah, merubah dinding permeabilitas pembuluh darah dan merubah $5-10 \% \mathrm{Hb}$ menjadi carboksi-Hb. Merokok juga dapat menurunkan vaskularisasi pembuluh darah jantung. ${ }^{24}$ Disamping itu, rokok dapat menurunkan kadar HDL kolesterol tetapi mekanismenya belum jelas. Makin banyak jumlah rokok yang diisap, kadar HDL kolesterol makin menurun. Perempuan yang merokok, penurunan kadar HDL kolesterolnya lebih besar dibandingkan laki-laki perokok. $^{24}$

Menurut penelitian Supriyono, Mamat (2008) Orang yang merokok memiliki peningkatan risiko sebesar 20-30\% untuk terkena penyakit jantung koroner 
dibandingkan dengan orang yang bukan perokok. $^{25}$

Mekanisme atau patogenesis rokok sehingga menyebabkan PJK merupakan hal yang kompleks. Berdasarkan klasifikasi American Hearth Assosiation (AHA) merokok sebagai faktor risiko independen, sebagai mayor risk factor. ${ }^{26}$ Menurut Martini dkk (2006) Telah diketahui bahwa rokok mengandung lebih dari 4000 jenis bahan kimia yang berbahaya termasuk bahan-bahan yang aktif secara farmakologik, antigenik, sitotoksik, mutagenik dan karsinogenik. Salah satunya adalah nikotin yang berperan merangsang pelepasan adrenalin, meningkatkan denyut jantung dan tekanan darah serta mengaktifkan trombosit. Selain itu nikotin juga bekerja mengubah metabolisme lemak sehingga meningkatkan asam lemak bebas dalam darah yang dapat menurunkan HDL. ${ }^{27}$

Penelitian ini sejalan dengan penelitian Kweon et al (2012) yang menyatakan bahwa tidak terdapat perbedaan kadar kolesterol yang bermakna secara statistik dengan nilai $p$ $=0.210 .^{28}$ Penelitian yang dilakukan oleh Yan Ling et al (2012) juga menunjukkan hasil bahwa tidak terdapat hubungan bermakna antara kebiasaan merokok dan kadar kolesterol, dengan nilai $\mathrm{p}=0.149 .{ }^{29}$

Penelitian serupa juga pernah dilakukan oleh Xie et al (2009) dan menunjukkan tidak terdapat hubungan antara status merokok, yang dibagi berdasarkan kadar kotinin pada plasma, terhadap kadar LDL serum. Pada analisa hasil, secara statistik, menunjukkan tidak terdapat perbedaan kadar LDL serum yang bermakna secara statistik, baik antara bukan perokok dan perokok aktif $(\mathrm{p}=0.706)$, bukan perokok dan perokok pasif $(\mathrm{p}=0.141)$, dan perokok pasif dan perokok aktif $(\mathrm{p}=0.119) .^{30}$

Hubungan yang tidak bermakna secara statistik yang ditunjukkan pada penelitian ini diduga disebabkan oleh adanya paparan terhadap asap rokok yang tidak dapat dihindarkan pada kelompok bukan perokok, dan hal ini dimungkinkan karena selain kebiasaan merokok masih tedapat berbagai faktor yang dapat mempengaruhi kadar kolesterol total diantaranya kebiasaan olahraga, rasio lingkar pinggang pinggul (RLPP), pola konsumsi, dan asupan serat.

\section{KESIMPULAN DAN SARAN}

\section{Kesimpulan}

Kesimpulan dalam penelitian ini adalah terdapat hubungan yang signifikan antara kebiasaan olahraga, dan rasio lingkar pinggang pinggul (RLPP), terhadap kadar kolesterol total pada pasien poliklinik jantung RSUD banten.

\section{Saran}

Sebaiknya para responden yang sudah memiliki kebiasaan olahraga, dan tidak merokok agar tetap mempertahankan dan menjaga kebiasaan tersebut agar tubuh tetap sehat dan terhindar dari penyakit-penyakit yang lain. Pada penelitian ini hanya meneliti kadar kolesterol total saja. Diharapkan pada 
penelitian selanjutnya meneliti bagian kolesterol lainnya seperti LDL, HDL, dan Trigliserida.

\section{DAFTAR PUSTAKA}

1. Waspadji, S. Diabetes Mellitus: Mekanisme Dasar dan Pengelolaan yang Rasional. dalam: Penatalaksanaan Diabetes mellitus Terpadu. Pusat Diabetes dan Lipid RSUP Nasional Cipto Mangunkusuma dan FKUI. 2007.

2. LIPI. Kolesterol. UPT-BALAI INFORMASI TEKNOLOGI LIPI. Pangan dan Kesehatan. 2009.

3. Kementerian Kesehatan Republik Indonesia. Riskesdas 2013. Jakarta. 2013.

4. Sartika, R. A. Pengkajian Status Gizi, Balai Penerbit FKUI, Jakarta. 2010.

5. Fathoni, M. Penyakit Jantung Koroer: Patofisiologi, Disfungsi Endothel, dan Manifestasi Klinis. edisi ke-1. Surakarta: UNS Press. 2011.

6. Mensink RP, Zock PL, Kester ADM, Katan MB, Effects of dietary fatty acids and carbohydrates on the ratio of serum total to HDL cholesterol and on serum lipids and apolipoproteins: a metaanalysis of 60 controlled trials. Am J Clin Nutr ;77, 1146-55. 2003.

7. FKM UI. Gizi dan Kesehatan Masyarakat. Jakarta: PT. Raja Grafindo Persada. 2014.
8. Anies. 2015. Kolesterol dan Penyakit Jantung Koroner. Yogyakarta: Ar-Ruzz Media.

9. Sumarni., Sari, Puspita. Surveilans Petanda Kardiometabolik Pada Sivitas Akademika Universitas Tadulako. Fakultas Kedokteran Universitas Tadulako, Palu, Sulawesi Tengah. Jurnal Kesehatan Tadulako Vol. 4 No. 1, Januari $2018: 1-56$

10. Salim, Agus., Samosir, Senam Aerobik Intensitas Sedang Menurunkan Kadar Kolesterol Total dan Indeks Massa Tubuh Wanita Penderita Obesitas. Fakultas Ilmu Keolahragaan, Universitas Negeri Medan. F2018.

11. Ingrid, Devina., Fathrah, Lily. Activity Test of Suji Leaf Extract (Dracaena angustifolia Roxb.) on in vitro cholesterol lowering.Jurnal Kimia Sains dan Aplikasi 21 (2) (2018): 54 - 58 .

12. Permata, Ririn., Eka, Amelia. Pemberian Air Perasan Jeruk Manis (Citrus sinensis) Meningkatkan Kadar LDL Kolesterol Serum. Vol 1 No 2 Mei 2018.

13. Almatsier, Sunita. Prinsip Ilmu Gizi Dasar. Jakarta: PT. Gramedia Pustaka Utama. 2009.

14. Par'i, Muhammad Holil. Penilaian Status Gizi. Jakarta : EGC. 2016.

15. Maulana, M. Penyakit Jantung: pengertian, penanganan dan pengobatan. Yogyakarta: Kata Hati. 2008.

16. Okvitasari, Yenny, dkk. Analisis FaktorFaktor Yang Berhubungan Dengan 
Kejadian Penyakit Jantung Koroner Di Ruang Poliklinik Jantung Di Rsud Ulin Banjarmasin. Jurnal Caring, Vol.2, No.2 Maret 2016.

17. Salim, Annisa Y., Nurrohmah, Anjar. Hubungan Olahraga Dengan Kejadian Penyakit Jantung Koroner Di Rsud Dr. Moewardi. GASTER Vol. 10 No. 1 Februari 2013.

18. Ketel IJG, Volman MNM, Seidell JC, Stehouwer CDA, Twisk JW, Lambalk CB. Superiority of Skinfold Measurements and Waist over Waistto-Hip Ratio for Determination of Body Fat Distribution in a PopulationBased Cohort of Caucasian Dutch Adults. European Journal of Endocrinology. 2007.

19. Ayuandira, Aulia. [skripsi] Hubungan Pola Konsumsi Makan, Status Gizi, Stres Kerja dan Faktor Lain dengan Hiperkolestrerolemia Pada Karyawan PT.Semen Padang Tahun 2012. UI: Fakultas Kesehatan masyarakat. 2012.

20. Supariasa, dkk. Penilaian Status Gizi. Jakarta : EGC. 2012.

21. Maryani, Elvia. Ratio Lingkar Pinggang Dan Pinggul Dengan Penyakit Jantung Koroner Di Rsud Kabupaten Sukoharjo. Buletin Penelitian Sistem Kesehatan Vol. 16 No. 1 Januari 2013: 73-82. 2013.

22. Sunarti. Maryani, Elvia. Ratio Lingkar Pinggang Dan Pinggul Dengan Penyakit Jantung Koroner Di Rsud Kabupaten
Sukoharjo. Buletin Penelitian Sistem Kesehatan - Vol. 16 No. 1 Januari 2013: 73-82.

23. Antika, Putri Rindi, Sigit Widyatmoko, Nining Lestari. Hubungan Rasio Lingkar Pinggang Panggul dengan Kadar Kolesterol Total pada Guru dan Karyawan SMA Muhammadiyah 1 dan 2 Surakarta. 2014.

24. Baraas, Faisal. Mencegah Serangan Jantung dengan Menekan Kolesterol. Jakarta: Gramedia Pustaka Utama. 2005.

25. Supriyono, Mamat. Faktor-Faktor Risiko Yang Berpengaruh Terhadap Kejadian Penyakit Jantung Koroner Pada Kelompok Usia < 45 Tahun (Studi Kasus Di Rsup Dr. Kariadi Dan Rs Telogorejo Semarang). Program Pasca Sarjana - Magister Epidemiologi. Universitas Diponegoro Semarang. 2008.

26. Kabo, P. Mengungkap Pengobatan Penyakit Jantung Koroner, Kesaksian Seorang Ahli Jantung dan Ahli Obat. Gramedia Pustaka Utama: Jakarta. 2008.

27. Yuliana S. Hubungan Antara Kebiasaan Merokok Dengan Kejadian Hipertensi Pada laki-laki usia 40 tahun ke atas di Badan Rumah Sakit Daerah Cepu. 2007.

28. Kweon S.S., Lee Y.H., Shin M.H., Choi J.S., Rhee J.A., Choi S.W., et al. Effects of Cumulative Smoking Exposure and Duration of Smoking Cessation on Carotid Artery Structure. Journal of the Japanese Circulation Society. 2012; 1-7 
29. Yan-Ling, Z., Dong-Qing, Z., CnangQuan, H., Bi-Rong, D. Cigarette smoking and its association with serum lipid/lipoprotein among Chinese nonagenarians/centenarians. Lipid in Health and Disease. 2012; 11: 1
30. Xie J., Hu D., Wang X., Luo Y., Wang J. Smoking State Determined by Cotinine and Arterial Stiffness. Japanese Circulation Society.2009;1-6 